\title{
The effect of zimmer twins as digital storytelling on students' writing narrative text
}

\author{
Dyah Wulandari ${ }^{1}$, Siti Maria Ulfa ${ }^{1}$, Arfiyan Ridwan $^{1}$ \\ ${ }^{1}$ English Education Department, STKIP PGRI Bangkalan, Indonesia
}

\section{Article Info}

Article history:

Received Jul 11, 2019

Revised Sept 20, 2019

Accepted Sept 26, 2019

\section{Keywords:}

Digital Story;

Narrative Text;

Writing, Technology;

Zimmer Twins.

\begin{abstract}
The objective of the research to compare of Zimmer twins website tool as digital storytelling than use nondigital in writing text narrative on students writing ability at the eleventh grade of MA Yayasan Sirojul Islam Sukolilo 2018/2019 academic year. Zimmer twins media is an animated movie maker based on the website for the students to create their short stories in movies with many emotion, etc. The sample of this research the Eleventh of MA YASI those are XI- 1 class as the experimental class, and the X1-2 class as the control class consisted of 20 students. The method in this research was a quantitative method. In addition, the design used was quasiexperimental research, and the instrument used a test. The research was taken by using non-random sampling. Moreover, this research was conducted through the following procedures: giving pre-test, applying treatments and giving post-test. The data analyzed and processed by using the statistic data calculation of ANCOVA by SPSS 23 program. The significant was shown by the students post-test mean in experimental class is 76.55 and the mean post-test in control class is 70.55. The result of the statistical hypothesis testing found from $\mathrm{p}$ value was 0.000 . It is lower than the level significant of 0.05 . If $\mathrm{p}$ value $\leq$ from the level significant 0.05 . It means that $\mathrm{H}_{1}$ was accepted and $\mathrm{H}_{0}$ was rejected. In conclusion, Zimmer twins media can be effective as media teaching to writing ability of narrative text at the eleventh-grade students of MA Yayasan Sirojul Islam Sukolilo.
\end{abstract}

Copyright $@ 2019$ Department of English Teaching. All rights reserved.

\section{Corresponding Author:}

Dyah Wulandari,

English Education Department, STKIP PGRI Bangkalan, Indonesia

J1. Soekarno Hatta No.52, Wr 07, Mlajah, Kec. Bangkalan, Kabupaten Bangkalan

Email: dyahwulandari6104@gmail.com

\section{Introduction}

In Indonesia, learning English is considered as EFL. English is a foreign language focuses on the main aspect involves language skills which combined with technology and these skills need to be mastered to learn English effectively. According to Laborda \& Royo (2007, p. 321) stated that technology is the importance of including ICT in the language curriculum the teacher may doubt technology or just be hesitant to include activities use a computer in their classroom. In recent years many of technology already has used in the education world especially to professional educators in teaching English for learners. Each of the students have a lower proficiency and afraid to writing because they are assured by themselves that they will make mistake to writing occasionally the students still have lack of confident feels to writing ability.

Teaching and learning in the school is guided by the content of Kemendikbud (2014) government of ministry of education and culture number 103 of the 2014 year concerning learning in basic education 
and secondary education which explains that in order to reach the quality that has been planned in syllabus design, there are principles that used as students as references for learning activities including (1) students are facilitated to find out; (2) students learn various learning source; (3) developing students creativity in the learning process; (4) fun and challenging learning atmosphere. Writing is one of ability skill to increase the students smoothly (Oshima \& Hogue, 2007). Based on the Standard Competence of English Curriculum 2013 the students are expected to be able to the written text of simple narrative text with focusing on the purpose, structure, and grammatical features of the text. The author teaches how to make narrative text with their previous knowledge see plot, actor, and point of view. The researcher wants to attempt for the learners with learning this digital story method as a multimedia system which makes the learners have a nervous feel to writing about the topic and also it might be the learners must have known technology to the learning process can easily and smoothly in the classroom area.

Zanz (2015) explains that digital storytelling is an educational tool to develop the students in creative and help to learn by doing. In general, the digital story mentions a small form of making a movie that consents the students to create storytelling to their study. Storytelling is not only potent in children education but also effective in all areas of higher education (Wang \& Zhan, 2010, p. 78). Education also required learning storytelling to improve ability in writing knowledge. To investigates use digital storytelling to improve this innovative technology in teaching and learning. The online platform used in this study is called the Zimmer twins it's a website design for children to share their creative story through animated stories (Jitpaisarnwattana, 2018). This research also focuses on digital media in the class which having access internet connection in a computer lab or laptop in order the teaching and learning process to students as a storyline can create a short story they can be creative and they can create text dialogues between characters and others.

This research is focused on the students' reactions that come out through digital tools to create a story and to create a movie (Schmoelz, 2018). The teacher should make a paper sheet to each students with a text narrative story after each students saw the topic stories in media teaching. It found the explanation of narrative in a curriculum guide in the teacher gives materials can help students that have difficulty feels to write. Based on the problem above, the teacher can make an enthusiast-class using storytelling is significant through its potential to contribute to language learning. The digital stories have found their way into language learning contexts. The activities of making and tell digital stories, which integrate sound and video images with dialog text to deliver the meaning content of stories. Therefore storytelling is the most traditional for teaching but the teacher still using books story in communication with the students so that it is a new way in the modern era. The researcher has a problem with the following questions: Do the students taught by Zimmer twins' media digital storytelling have better writing narrative story text achievement than those taught by non-digital in storytelling?.

\section{Method}

This research is quantitative research. The experimental research has several designs including preexperimental design, true experimental design, factorial design, and quasi-experimental design. The researcher used a quasi-experimental to design this study. Quasi-experiment design involves in an educational setting, it is impossible choosing sample randomly of the population and assigns to a different class, and the researcher only assigns at random different treatments to two different classes (Charles, 1995) in (Latief, p. 96). This quasi-experimental research was used to know differences in the ability of the treatment class and the non - treatment class. The design is represented by a nonequivalent control group design.

Table.1 Research design of quasi experimental
\begin{tabular}{|c|c|c|}
\hline $\mathrm{O}_{1}$ & $\mathrm{X}$ & $\mathrm{O}_{2}$ \\
\hline $\mathrm{O}_{3}$ & - & $\mathrm{O}_{4}$ \\
\hline
\end{tabular}

(Sugiyono D. P., 2015, p. 79)

Explanation:

O1: Giving the pre-test experimental class O2: Giving

Post-test in the experimental class. O3: Giving pre-test

in control class

O4: Giving Post-test in the control class

$\mathrm{X}$ : Treatment in the experimental group of teaching writing narrative text through Zimmer twins as digital storytelling.

- : Teaching and learning model that is not the same as the experimental class.

In this research, the researcher decided to do this research to the students of MA Yayasan Sirojul 
Islam since most of them were seemed totally matchto join this research because of their condition. Based on the design of this research, the researcher took decision to point two classes of the eleventh class out: 20 students in each XI social 1 and XI social 2. The sampling techniques chosen by the researcher was a nonprobability sampling technique. The researcher determines the type of sampling that is purposive sampling. The technique of deciding this sample was selected of judgment by the teacher or researcher to takes 20 students. This research uses three variables; the independent variable is a variable that influences the dependent variable and variable covariate to determine the effect of covariate with the dependent variable. In this research, the independent variable was Zimmer twins as animation movies of digital storytelling. The dependent variable is the students' writing ability, and narrative text before giving treatment (pre-test) as covariate variable to find out the influence of ability of the initial score students who differ significantly.

The instrument of this research was pre-test and post-test. The test is the form of a narrative essay after the students watch an animated movie in Zimmer twins website. The test will be used as source information on what to extend students initial ability to write a narrative story. All students already know that narrative is a text which is commonly used to tell an imaginary story. The test gave in the beginning pre-test and in the end post-test, the pre-test was a form of essay used to measure initial ability in writing a narrative story. Then post-test can be used to measure ability in writing the narrative story after students give a treatment of learning Zimmer twins.

Reliability is also needed to create a good test because a test must be reliable as a measuring instrument; the researcher used the product-moment to measure the reliability of the research using testretest because in this class the researcher gives the same test to the students at a different time. To measure whether the test was reliable or not, the researcher used the formula Cronbach's Alpha is .880 that the test has very high reliability. Validity is when a test must measure what it is intended to measure and what has been taught. It means that students have to write the story that they have already learned. To valid, the researcher uses content validity because content validity is the extent to which a measuring instrument. Before the instrument is applied to students, the author consults with experts judgments is lecturer whether the instrument is appropriate or not to measure the variable of research. The data was taken by doing pretest, treatment, and post-test in experimemntal group and pre-test and post-test in control group. After collecting data, the researcher analyzed the result of this quasi- experiment research by using ANCOVA which stood for analysis of Covariance as it was applied to compare the post-test scores of the two groups and pre-test before treatment.

\section{Result and Discussion}

Table 2. the result of Pre- Test Descriptive Statistics

\begin{tabular}{|c|c|c|c|c|c|c|c|}
\hline & \multirow{2}{*}{$\frac{\mathrm{N}}{\text { Statistic }}$} & \multirow{2}{*}{$\frac{\text { Min }}{\text { Statistic }}$} & \multirow{2}{*}{$\frac{\text { Max }}{\text { Statistic }}$} & \multirow{2}{*}{$\frac{\text { Sum }}{\text { Statistic }}$} & \multicolumn{3}{|c|}{ Mean Std.Deviation } \\
\hline & & & & & Statistic & Std. Error & Statistic \\
\hline $\begin{array}{l}\text { Pretest } \\
\text { control }\end{array}$ & 20 & 46 & 78 & 1.342 & 67.10 & 1.721 & 7.698 \\
\hline $\begin{array}{c}\text { Pretest } \\
\text { Experiment }\end{array}$ & 20 & 42 & 70 & 1.207 & 60.35 & 1.655 & 7.400 \\
\hline Valid N (listwise) & 20 & & & & & & \\
\hline
\end{tabular}

The result of students of both class score was low scores, they got a bad score. And the researcher know based on the total number of pre-test score was 1.207 for experimental class and 1.342 for control class and that mean was 60.35 for experimental class with the total number of students was 20 because they understood about the topic discussed and some words that used in writing a paragraph. But, some students still get difficulties in vocabulary so the researcher gave more attention and 67.10 for control class with a total number of students was 20 .

Table 3. The result of Post-test Descriptive Statistics

\begin{tabular}{|c|c|c|c|c|c|c|c|}
\hline & $\mathrm{N}$ & Min & Max & Sum & $\mathrm{Me}$ & & $\begin{array}{c}\text { Std. } \\
\text { Deviation }\end{array}$ \\
\hline & Statistic & $\begin{array}{l}\text { Statis } \\
\text { tic }\end{array}$ & $\begin{array}{l}\text { Statis } \\
\text { tic }\end{array}$ & $\begin{array}{l}\text { Statis } \\
\text { tic }\end{array}$ & $\begin{array}{l}\text { Statis } \\
\text { tic }\end{array}$ & Std. Error & Statistic \\
\hline Posttestcontrol & 20 & 60 & 84 & 1410 & 70.50 & 1.099 & 4.915 \\
\hline Posttestexperiment & 20 & 71 & 86 & 1531 & 76.55 & .936 & 4.186 \\
\hline Valid N (listwise) & 20 & & & & & & \\
\hline
\end{tabular}


Based on the results of the total number of post-test above, the experimental group students score higher than the pre-test, this happened because students already understood more about a narrative text. The score of the control group 1.410 with a mean score of 70.50 and the score of experimental group 1.531 with a mean score 76.55. Based on the table above, the control group scores lower than the experimental group, this occurs because the control group does not get treatment. The control group was only taught used conventional methods.

Hypothesis Testing

Table 4. Tests of Between-Subjects Effects

Dependent Variable: Writing

\begin{tabular}{crrrrr}
\hline Source & Type III Sum of Squares & df & Mean Square & F & Sig. \\
\hline Corrected Model & $467.619^{\mathrm{a}}$ & 2 & 233.810 & 12.531 & .000 \\
Intercept & 1881.094 & 1 & 1881.094 & 100.818 & .000 \\
pretest & 101.594 & 1 & 101.594 & 5.445 & .025 \\
Media & 466.331 & 1 & 466.331 & 24.993 & .000 \\
Error & 690.356 & 37 & 18.658 & & \\
Total & 217395.000 & 40 & & & \\
Corrected Total & 1157.975 & 39 & & & \\
\hline
\end{tabular}

a. $\mathrm{R}$ Squared $=.404$ (Adjusted R Squared $=.372$ )

Based on the table of ANCOVA model above, the score of media is successful it is a lower than alpha $(0.05)$ is $.000 \leq 0.05$ and the significant score pre-test lower than alpha $(0.05)$ is $025 \leq 0.05$. This ANCOVA model, the pre-test as a covariate was influence because the initial ability of the students scores between the two groups in pre-test was significantly different and this affect on the significantly difference mean in writing skill. The difference mean of writing skill by using media variable were significantly can influence the difference mean in writing skill, so that pre-test and media have significantly difference mean scores of students in writting narrative text.

Based on the purpose above, the result of ANCOVA from P-value (.000) was lower than alpha $\leq$ 0,05 it is means that $\mathrm{H}_{1}$ was accepted and $\mathrm{H}_{0}$ was rejected of the hypothesis. If $\mathrm{P}$-value $\leq$ alpha $(\alpha)$, it means that $\mathrm{H}_{1}$ was accepted and $\mathrm{H}_{0}$ was rejected. It showed that there is was an influence of Zimmer twins as media digital storytelling on the students' writing narrative text at the eleventh grade of MA Yayasan Sirojul Islam.

From the data above, the researcher analyses that there was a significant difference between the students who are taught used Zimmer twins and those who are taught not used Zimmer twins in writing class. Writing is communication into written form. Cheung (2016) emphasized to teach writing effectively, the teacher must be clear knowledge of the skill and process that are involved, the teacher must know of a part writing process. The author gave a writing test about the narrative text to know the result of the score by using five-components or aspect of writing skills. Those aspects were content, organization, vocabulary, grammar, and mechanic. Those aspect adapted from Weigle (2002). After scoring those aspects, the researcher used an analytical scoring, it means that the material of narrative text is clearly of researcher uses Zimmer twins to created animated and tell the story to the students understood about generic structure of a narrative text and they can increase the aspect to be better.

From the total score the mean scores pre-test as the initial score in writing skill, the control group got a score is 67.10 and in experimental group the score was 60.35 in the pre-test. The result of the pretest score showed low on all aspect, because the students have low scores on pre-test that can influence the writing of narrative text, this happens because they have difficulty to processing words especially vocabulary and grammar errors to write narrative text. After that, the author gave a three times treatment for experimental group to help the students become more enthusiastic, active in learning English by using media, in contrast to the control group by using conventional method. The researcher gave post-test to students in the control and experimental groups. From the data shows that there are differences from the mean score post-test of the control and experimental groups on post-test it has mean 76.55 while, the posttest score of students who are taught by conventional method has mean 70.50 . It means that the average of 
students taught by using Zimmer twins as media on writing narrative text was high than the students taught by conventional method. From each score the experimental group post-test results were higher than the control group.

The research result was in line with Anderson, et. al (2015) Explain that Zimmer twins are an easy way to be applied by the students as a story starter in the classroom. A teacher must present the site and shows a short animation movie to students are well-known with the Zimmer twins. Then the students could be seen short movies and students make the story until finished from the students created a movie. The majority of students at the Yayasan Sirojul Islamic are not learning English through learning media such as Zimmer twins because they are still learning from the textbook so that use of Zimmer twins as a media for website animation gets better results compared to the conventional technique.

Jitpaisarnwattana (2018) noted that zimmer twins as digital storytelling they can encourage to use the vocabulary they had learn in the classroom contribute to creating a movie making tool to learn many vocabularies from dialog text and emotion to be able completed the videos movie. This is because in the Zimmer twins media animation has a variety of visual images, dialog texts, feelings and expressions of various characters of the stories made by the students themselves. In the animated movies made by students that have advantages among others can improve the students understanding ability on the material delivered by the teacher, so that they can write narrative texts became more coherent in the animated movie also contain dialogues text that uses varied expression so students can increase their vocabulary in writing narrative text.

Prins, et. al (2017) argues that the narrative is an easy text to write because of the context following a chronological of the story through an expression of different media animation. The students had big enthusiasts of made short animated movies based on their own each story in Zimmer twins then they wrote of narrative text. It happened because Zimmer twins website as a digital storytelling it is unique media which easy to implement the ideas, imagination and can make a creative short movie by using many scene expression, etc. Then, it can be helpful good media to the students writing ability effectively and interested in the teaching-learning.

In this research, the researcher concluded that teaching writing by using Zimmer twins as media digital storytelling make the students have interested and motivation to write a narrative text. The researcher gave treatment in a group for increase the students motivation. It could be shown when the researcher was teaching narrative text by using Zimmer twins as digital storytelling on the website. This experimental research was declared successful, easily to be applied and enjoyed in following a teaching-learning process. And they can write English well and it could be proved by a good result in doing their assignment.

\section{Conclusion}

Based on the result of data analysis, the researcher summarizes that writing ability is an issue of students at MA Yayasan Sirojul Islam on this research. The research problem on this research is to find out the differences between students who learned used Zimmer twins as digital storytelling and those who are not using nondigital storytelling. This design experimental use quasi-experimental consisting of two groups are experimental and control group. The result data showed that the students of the experimental class were a significant difference which used Zimmer twins in learning narrative writing got a better score than the control group. Teaching narrative writing with Zimmer twins as digital storytelling did had better in writing at the eleventh class of MA Yayasan Sirojul Islam. This research was successful because this method gives a good contribution to the students' in writing then it could become a stimulation to write the narrative text also the students understood of the part of the story after they see the animated movies. The students can express their creative thought about making animated stories from Zimmer twins. Therefore, it will make the teaching and learning process would be more fun and interesting. The researcher hopes that the teachers are expected to be completed with a guidebook that steps to make animated movies from websites or software as digital storytelling and able to apply teaching media from the Zimmer twins media in English learning because of the effective results compared to conventional learning methods. This is also expected to be a motivator for teachers to continue to innovate and enhance students' creativity in the learning process. The researcher hopes that the student in writing narrative text is expected to make the process of learning English more enjoyable. Besides, students' are expected to be more active so that the ability to write their narrative texts becomes better. The next researcher can use this Zimmer twins media to teach English at a different level, grade, subject and topic to develop the teaching and learning process. The media Zimmer twins can be used and developed as the stabilization media animation in website to teach the students not only in writing but also in other aspects as like speaking skill. 


\section{References}

Anderson, S., Bellow, A., \& Byrne, R. (2015). A comprehensive introduction to using technology in all K12 classrooms. The Super Book of Web Tools for Educators, 8-25.

Bozdogan, D. (2012). Content Analysis of ELT Students Digital Stories for oung learners. Research on Youth and Language, 2(6), 126-136.

Charles, C. M. (1995). Introduction to Educational Research (2 nd ed.). New York: Addison Wasley Longman .Inc.

Cheung, Y. L. (2016). Teaching Writing Chapter 12. In W. A. Renandya, \& H. P. Widodo, English language Teaching Today: Buiding a Closer Link Between and Practice (pp. 1-21). New York: NY: Springer International.

Jitpaisarnwattana, N. (2018). Fostering Learner Autonomy in Foreign Language Classroom : A Digital Storytelling Project. Journal of Foreign Language Education and Tecnology, 3(2).

Jitpaisarnwattana, N. (2018, December 29). Students Attitude toward the Use of Digital Storytelling in foreign Language Classroom : The Zimmer Twins Project. rEFLections, 25(2), 59 - 75.

Kemendikbud. (2014). Pembelajaran dan Pendidikan Menengah. Jakarta: The Ministry Education and Culture Republic Indonesia.

Kilickaya, F. (2011, December 5). Zimmer twins Website review. Asia Pacific Association for Computer Assisted Language Learning, 7-10.

Laborda, G. J., \& Royo, M. T. (2007). How to teach English with technology ;Book Review. In N. Hockly, \& G. Dudeney, How to teach English with technology (p. 192). Spain: Pearson- Longman.

Latief, M. A. (2016). Research Method on Language Learning an Introduction. Malang: UM Penerbit \& Percetakan.

Oshima, A. (2007). Introduction to academic writing (3nd ed.). New York: Pearson Education Inc.

Prins, R., Avraamidou, L., \& Goedhart, M. (2017). Tell me a Story: the use of narrative as a learning tool for natural selection. In Educational Media International (Vol. 54). Netherland: Informa UK Limited, trading as Taylor \& Francis Group.

Sanz, A. G. (2015). Digital Storytellingas an Innovative in English for Specific Purpose. Procedia and behavioral Sciences Elsevier, 8(17), 110-116. doi:10.1016/j.sbspro.2015

Schmoelz, A. (2018, February 3). Enabling co -creativity through digital storytellling in education. Thingking Skills and Creativity, 02(10).

Sugiyono, D. P. (2015). Metode Penelitian Kuantitatif, Kualitatif, dan R\&D. Bandung: Alfabeta,CV. Sugiyono, P. D. (2016). Statistika untuk penelitian. Bandung: Penerbit Alfabeta.

Wang, S., \& Zhan, H. (2010). Enhancing Teaching and Learning with Digital Storytelling. International Journal of Information and Communication Technology Education, 6(2), 76-87.

Weigle, S. C. (2002). Assesing Writing; cambridge language assesment series (3rd ed.). New York: Cambridge University Press. 